\title{
De Praepositione: The Emerging of Donatus's Thought on Syntax?
}

\author{
Castrenze Nigrelli \\ Dept. of Scienze Umanistiche, University of Palermo \\ Viale delle Scienze, Ed. 12, 90128, Palermo, Italy \\ Tel: 39-328-019-2208Ｅ-mail: castrenze.nigrelli@unipa.it
}

Received: May 9, 2020

doi:10.5296/ijl.v12i3.17101
Accepted: June 17, 2020

Published: June 27, 2020

URL: https://doi.org/10.5296/ijl.v12i3.17101

\begin{abstract}
The paper aims at investigating the syntax treatment in late Antiquity through the analysis of the description of prepositions within Donatus's Artes. As far as an organic and dedicated description of syntax is concerned, the Roman tradition of grammatical studies in late Antiquity shows an overall gap. However, reflections on syntax emerge from the parts of speech descriptions made by grammarians. The ultimate purpose of this paper is to understand if, and to what extent, traces of emerging thought on syntax can be found in Donatus's description of prepositions. These are regarded as a syntactic object of study by the modern linguistic theory. To that end, the paper focuses on the textual analysis of the de praepositione sections included in both Donatus's Ars maior and minor, with particular reference to metalinguistic terminology. The analysis highlights some emerging traces of Donatus's reflection on syntax, although his concept of syntax is distant from the modern one, particularly in reference to a double perspective that concerns his description of the relation between praepositio and casus.
\end{abstract}

Keywords: Latin, Donatus, Syntax, Preposition, Metalanguage

\section{Introduction: The Gap of Syntax in the Late Antique Grammatical Tradition}

Roman grammarians of late Antiquity, especially Donatus (IV AD) and Priscian (V-VI AD), have completed the process of adapting thoughts, categories, and terminology of the Greek grammatical tradition to Latin, so providing a range of tools of metalinguistic reflection, which has been fundamental for the analysis of Latin and other languages throughout many centuries (cf. Poli 1990: 149 ff.; among others, see also Robins 1967; Baratin 2014; De Paolis 2015). (Note 1) 
Overall, syntax has received very little attention by Greek and Roman ancient grammatical studies, and the ancient grammatical tradition shows a lack of dedicated and organic syntactic descriptions, in favor of a more word-oriented linguistic analysis (Law 1997: 266 f.; among others, see also Donnet 1967; Robins 1967: 46). Although there are some remarks on syntax in the grammar attributed to Dionysius Thrax (II BC) - for example, in the concept of word as the minimal unit of the sentence (which is the maximum one) or in the classification of the parts of speech - any specific section regarding syntax lacks, and the concept of $\sigma u ́ v \tau \alpha \xi 1 \zeta$ (and $\sigma \dot{v} \theta \varepsilon \sigma 1 \varsigma$ ) is very far from the modern idea of syntax as the analysis of the internal structure of sentences.

The first systematic treatment of syntax which dates back to Antiquity is the one by Apollonius Dyscolus (II AD). This work adopts basic elements of Stoic logic and is also linked to Dionysius's and later works (on the role of Stoic logic in the development of syntactic study throughout Antiquity and the Middle Ages, see recently Luhtala 2020). Priscian would refer to Apollonius's authority in Institutiones Grammaticae, with particular regard to books XVII-XVIII, which are the unique Roman example of description dedicated to syntax (de constructione). (Note 2) Both Apollonius's and Priscian's works lack central syntactic ideas such as government, with reference to the fact that items such as verbs or prepositions can oblige other words to be inflected with a specific case within the same construction (cf. Fredborg 2014: 220). Metalinguistic terminology concerning syntax is quite variable at least until the $13^{\text {th }}$ century, when terms such as regere (regimen) would be widely used by groups of scholars of the speculative grammar approach, in particular the modistae, in order to convey the concept of government as developed in the medieval theory; until then, different terms are metaphorically used in order to denote this concept (cf. Law 1997: $261 \mathrm{ff}$.). Furthermore, within the repertoire of ancient grammarians, terminology for the notion of sentence and word within the sentence is also ambiguous. On the one hand, terms such as oratio, sermo (or Gr. $\lambda \dot{\varepsilon} \xi 1 \zeta$, $\lambda$ ó $\gamma \mathrm{o}$ ) can convey the modern notion of sentence, according to one of their senses, on the other hand, these terms can also cover the notions of word, sentence, clause, enunciation, text. Similarly, there is ambiguity also on the notion of word as

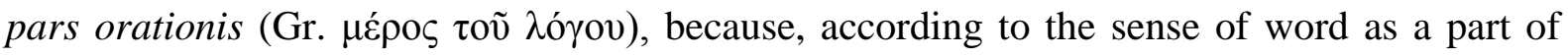
speech, this phrase also refers to that of word class, i.e. to part of speech in the strict sense (Swigger \& Wouters 2003: 33; cf. Law 1997: 263). (Note 3)

Using an effective metaphor, in antique grammatical theory, syntax is fragmentary and surreptitious: it «entre par les interstices d'un édifice de nature essentiellement graphophonétique, morphologique et catégorielle», although it can emerge from the description of certain parts of speech: for example, this is true for conjunctions, already in Dionysius Thrax, as for Greek, and in Donatus, as for Latin (Swiggers \& Wouters 2003: 32 ff.; cf. Pugliarello 2013 on coniunctio in Donatus). (Note 4)

Donatus was active in Rome around the mid $4^{\text {th }}$ century, and his work was one of Priscian's sources (Holtz 1981: 239 ss.). Donatus's main grammatical works are his two Artes. The Ars minor (GL IV 352-366) represents a short manual for beginners, concerning Latin partes orationis, (Note 5) as also shown by the systematic use of the question-and-answer scheme, whereas the Ars maior (GL IV 367-402), consisting of three books, is a longer treatise and 
deals with partes orationis (book II), phonetics, prosody, metrics, punctuation (book I), and stylistic issues (book III). (Note 6) As far as syntax is concerned, Donatus's dissertation lacks an organized description, as a dedicated section has no place within either Donatus's Artes (cf. Brugnoli 1985; Petrilli 1996). Actually, traces of reflection on syntax emerge from the descriptions of certain parts of speech.

The present paper aims at investigating Donatus's syntax treatment, limited to his description of prepositions. These are definitely connected to syntax from the perspective of the modern linguistic theory. The de praepositione sections will be analyzed within both Donatus's Ars maior and minor (GL IV 389, 28-391, 24; 365, 10-366, 11), with particular reference to metalanguage, in order to trace emerging theoretical reflections on syntax. The results will be presented and discussed through a selection of significant examples.

\section{Analysis of the De Praepositione Sections in Donatus's Ars Maior and Minor}

The textual analysis of the de praepositione sections included in the Donatian Artes first takes into consideration the definition of praepositio of the Ars maior, which overlaps that of the Ars minor: (Note 7)

(1) Praepositio est pars orationis, quae praeposita aliis partibus orationis significationem earum aut mutat aut conplet aut minuit (GL IV 389, 19-20)

"Preposition is a part of speech which placed before other parts of speech either modifies, completes or attenuates their particular sense"

Within the Donatian definition of praepositio (calque of Gr. $\pi \rho$ ó $\theta \varepsilon \sigma 1 \varsigma<\pi \rho o-\tau i \theta \eta \mu 1$ "to put before", equivalent of Lat. prae-pōno) there are no terms that refer directly to syntax. (Note 8) Nevertheless, a syntactic perspective would seem to be traceable in the fact that preposition, identified as pars orationis - "part of speech", according to one of the possible senses of oratio - is defined in the relation with the other partes orationis. (Note 9) However, it is not possible to identify a real syntactic relation between prepositions and other parts of speech, i.e. a relation which is intended as government, subordination in modern terms, but only a relation concerning order, position. As shown by the use of the perfect participle of the verb praepōno "to put before", which is a compound of pōno "to place" and a corradical of praepositio, it is characteristic of the class of prepositions to be linearly "placed before" (cf. praeposita) other parts on the level of the expression: thus, the description in (1) refers to a mere ordered arrangement of elements. (Note 10) Furthermore, put in these terms the syntactic perspective included in the Donatian definition is connected to a semantic and functional perspective, as underlined by the final part of the definition (cf. significationem earum aut mutat aut conplet aut minuit): placed before the other partes orationis, prepositions have the function of modifying, completing, or attenuating their sense (significatio), that is the occasional semantic value that words assume in the particular context in which they occur. (Note 11) In the light of this analysis of Donatus's definition of preposition, the question remains as to whether the deverbal word praepositio has to be understood either as a nomen actionis, a nomen rei actae (cf. Praepositio [...] praeposita), or in both senses. In this regard, the passage of the Ars maior immediately following the 
definition and in which the partes orationis that prepositions can precede are listed, is significant: (Note 12)

(2) nam aut nomini praeponitur, ut invalidus; aut pronomini praeponitur, ut prae me, vel subponitur, ut mecum tecum nobiscum vobiscum; aut verbum praecedit, ut perfero, aut adverbium, ut expresse, aut participium, ut praecedens, aut coniunctionem, ut absque, aut se ipsam, ut circumcirca. (GL IV 389, 20-24)

"in fact either it (scil. preposition) is placed before a name, as in invalidus; or before a pronoun, as in prae me, or it is put behind it, as in mecum, tecum, nobiscum, vobiscum; or it precedes a verb, as in perfero, or an adverb, as in expresse, or a participle, as in praecedens, or a conjunction, as in absque, or itself, as in circumcirca"

As it can be deduced from the use of compounds of pōno, i.e. praepōno "to put before" and subpōno "to put under", the relation between prepositions and other partes is not syntactic in the strict sense and it is described, also in this case, in terms of linear order. Both occurrences of praeponitur refer in fact to the linearly-preceding position that prepositions occupy with respect to nouns or pronouns, whereas subponitur refers to the possible postpositive position of specific prepositions respect to specific personal pronouns. With reference to the position of prepositions with respect to verbum, adverbium, participium, coniunctio, praepositio, the use of praecédo "to go before, precede" may seem interesting in comparison with that of praepōno and subpōno. The speaker's choice seems to come into play here (see also, below, (6) and (9)-(12)). On the one hand, the use of the passive form of praepono would seem to amount to a choice made by the speaker in relation to prepositions: in invalidus, for example, it is the speaker who places in before validus; on the other hand, the choice of praecédo would seem to exclude any speaker's choice: in expresse, for example, the speaker does not place $e x$ before presse, but draws directly on the univerbate form, which he finds ready to use. If what has just been said is convincing, the term praepositio would be understood both as nomen actionis and nomen rei actae.

As it can be seen from the comparison between the examples invalidus and prae me, on the terminological level there is no distinction between a prefixed (and preverbal) preposition, i.e. morphosyntactically cohesive to the element that follows (e.g. in in invalidus), and a proper preposition, i.e. preceding a nominal but being separate from it (e.g. prae in prae me). (Note 13)

Actually, the previous distinction refers to that which Donatus articulates in (3) using the terms casus and loquella. In the context of the description of praepositiones, these terms are co-hyponyms of dictio "word": in fact casus indicates an independent case-inflected form, which is preceded by a preposition, but from which it is separated, e.g. me in prae me; loquella indicates, instead, a word which is preceded by a preposition, but to which it is also cohesive in compounding, e.g. validus in invalidus (cf. Law 1997: 263). (Note 14) Therefore the Donatian notion of casus does not refer, in modern terminology, to the inflectional marker that a preposition, as the head of a prepositional phrase, compulsorily selects. Besides the notion of phrase, also that of inflectional morpheme/suffix was actually absent in late-Antique morphological theory, according to which, a vox (i.e. "word" as a 
morphophonetic unit) could change its terminatio (cf. termino "to conclude; to mark the boundaries of"), i.e. the final phonetic element (littera) or syllable (syllaba). In particular, the relation between prepositions and casus, the latter understood as a case-inflected nominal preceded by a preposition, represents a central issue with respect to the purpose of the present analysis, as it shows traces of a reflection on syntax. Casus is in fact the only accidentia of prepositions, that is, their only "accessory feature", as shown by some Donatus's passages: Praepositioni accidit casus tantum "Only casus, as accessory element, accompanies prepositions" (GL IV 390, 2-3), and Praepositioni quot accidunt? Vnum. Quid? Casus tantum. "How many accessory elements accompany prepositions? One. Which one? Only casus" (GL IV 365, 11-12). (Note 15) Within Roman grammatical tradition, accidentiae - as genus "gender", numerus "number", tempus "tense" - corresponded to what Dionysius Thrax and Apollonius Dyscolus identified as $\pi \alpha \rho \varepsilon \pi o ́ \mu \varepsilon v \alpha$ (< $\pi \alpha \rho \varepsilon ́ \pi о \mu \alpha$ " "to accompany, attend”), i.e. those "concomitant qualities" typical of the parts of speech, to which they were added, producing formal modifications. (Note 16)

Casus is therefore described by Donatus as an accidental element, an accessory of prepositions. Therefore it is possible to see a certain syntactic relation between preposition and casus in the fact that the latter is a nominal inflected with a specific case. However, from the perspective of prepositions, it is worthy of note that its relation with casus seems to be described by Donatus also in opposite terms, as it can be seen from the passage (3), taken from Ars maior:

(3) praepositiones aut casibus serviunt aut loquellis aut et casibus et loquellis. aeque aut coniunguntur aut separantur aut et coniunguntur et separantur. coniunguntur, ut di, dis, re, se, am, con; dicimus enim diduco, distraho, recipio, secubo, amplector, congredior: separantur, ut apud penes: coniunguntur et separantur ceterae omnes. (GL IV 389, 24-28)

"Prepositions accompany either declined nominals or words in general, or both declined nominals and words in general. In addition, they (scil. prepositions) either occur as cohesive to or separated from words, or they can occur as both cohesive and separated. For example, di, dis, re, se, am, con occur as cohesive: we say in fact diduco, distraho, recipio, secubo, amplector, congredior. For example, apud or penes occur as separated. All the others occur as both cohesive and separated"

In (3) the relation between prepositions and declined nominals or other words is taken into account. In the first case, prepositions precede a declined nominal and remain separate from it, as in apud villam, an example found in Ars minor (GL IV 365, 16). In the second case, prepositions form compounds by cohesion with words, as in dis-traho. The relation under discussion is expressed with the verb servio "to serve, be useful, be at the service of". Thus, it is prepositions that play an ancillary function with respect to a declined nominal or another word, and this configures an overturned perspective in comparison with that from which casus is described as an accessory feature of prepositions. In (3) prepositions are therefore "at the service of" casus and loquella: in other words, prepositions accompany both with a 
certain aspect of servitude, functioning as ancillary elements that contribute to the specific sense of both.

If what has been said so far appears convincing, therefore it is clear that Donatus treats the relation between prepositions and declined nominals (i.e. casus) in two different ways that are not exactly consistent with each other. On the one hand, prepositions play a central role with respect to declined nominals, which are accidental elements of prepositions. On the other hand, declined nominals play the central role, in the identification of which prepositions simply participate. The same consideration cannot be made about the relation between prepositions and words in compounds (i.e. loquellae): prepositions accompany loquellae, join them contributing to their meaning, but loquellae cannot be considered as accidental elements of prepositions in any case.

Congruent with (3) is (4), which is included in Ars minor:

(4) Quae praepositiones sunt quae dictionibus serviunt et separari non possunt? Di dis re se am con. Quo modo? Dicimus enim diduco distraho recipio secubo amplector congredior. Quae sunt quae coniungi non possunt? Apud et penes. Quae coniunguntur et separantur? Reliquae omnes. (GL IV 366, 7-11)

"What are the prepositions that accompany words and cannot be separated from them? Di, dis, $r e, s e, a m, c o n$. How is this characteristic achieved? In the fact that we say diduco, distraho, recipio, secubo, amplector, congredior. What are those that cannot be cohesive to words? Apud and penes. What are those that can be both cohesive to and separated from words? All the rest."

As in (3), also in (4) Donatus uses the verb servio to convey the ancillary function of prepositions, in this case in relation to dictio, a term that refers generically to the notion of "word", so leaving aside the distinction between casus and loquella.

Again in Ars minor, immediately after having established that casus is the only accessory feature of prepositions, Donatus specifies that he is talking about the casus accusativus and ablativus, i.e. nominals which are respectively inflected with the accusative or the ablative case. The grammarian then lists, providing examples, the prepositional forms that go together with an accusative-inflected nominal and those followed by an ablative-inflected one. However, the matter is treated schematically by Donatus. Furthermore, in order to express the relation between prepositions and declined nominals he uses a terminology which is different from what seen so far:

(5) Da praepositiones casus accusativi. Ad apud ante adversum [...]. Quo modo? Dicimus enim ad patrem, apud villam, ante aedes, adversum inimicos [...]. Da praepositiones casus ablativi. A ab abs [...]. Quo modo? Dicimus enim a domo, ab homine, abs quolibet [...]. (GL IV 365, 13-27)

"List the prepositions of accusative case. Ad, apud, ante, adversum [...]. How is this characteristic achieved? In the fact that we say ad patrem, apud villam, ante aedes, 
adversum inimicos [...]. List the prepositions of ablative case. A, $a b, a b s$ [...]. How is this characteristic achieved? In the fact that we say a domo, ab homine, abs quolibet [...]"

In the praepositiones casus accusativi/ablativi formula, the relation between praepositio and casus is expressed with the genitive, to be interpreted as a genitive of quality. In the question, it is requested to list "the prepositions of the accusative casus/of the ablative casus", that is, the prepositions which have the quality of the accusative casus/of the ablative casus: in other words, the prepositions which have the accessory feature of being accompanied by a nominal which is accusative-inflected or ablative-inflected. (Note 17) Also in (5), therefore, Donatus's reflection on syntax proves to be far from the modern concept of syntax, as he describes the relation between prepositions and inflected nominals in terms of ancillary nature: casus is accessory of praepositio. Continuing the passage (5), (6) refers to prepositions that can go together with nominals which are declined with both the accusative and the ablative case:

(6) Da utriusque casus praepositiones. In sub super subter. In et sub quando accusativo casui iunguntur? Quando vel nos vel quoslibet in locum ire isse ituros esse significamus. Quando ablativo? Quando vel nos vel quoslibet in loco esse fuisse futuros esse significamus. (GL IV 365, 27-30)

"List the prepositions of one case and the other. In, sub, super, subter. When are in and sub joined to a nominal which is declined with the accusative case? When we mean that either we or anyone go/goes, went, will go somewhere. When are they joined to a nominal which is declined with the ablative case? When we mean that either we or anyone are/is, were/was, will be somewhere"

The formula of the first question (cf. utriusque casus praepositiones) shows the use of the genitive of quality in a similar way to the passage in (5): in fact it is requested to list the prepositions which can have as an accessory feature both an accusative- and an ablative-inflected nominal. The subsequent questions (quando accusativo casui iunguntur?/Quando ablativo?) aim instead to further explore the distinction between the use of both in and sub with, on the one hand, an accusative casus and, on the other hand, an ablative one. Within the description, Donatus's use of iungo "to join; connect" in the passive form, in order to clarify the relation between prepositions and declined nominal forms, is certainly interesting. Somehow, (6) creates the impression that the preposition actually is the accessory element which is added to the declined nominal. Furthermore, similarly to what discussed in (2) regarding the use of the passive form of praepōno (as opposed to praecēdo), also iunguntur refers to the speaker's perspective, who has the opportunity to make a choice and put the preposition before a nominal which is declined with either the accusative or the ablative case, according to his intention. In the passage, in fact, the reference to the semantic level (cf. significamus) is explicit. In the light of what just said, as well as it can be seen in the successive passages (7) and (9)-(12), a double perspective emerges from Donatus's description of prepositions: on the one hand, the hypostasis of prepositions, which are described with their features; on the other hand, the intervention of the speaker's intention, when there is the possibility of making a choice in the use of prepositions. The reading of Ars minor continues with (7): 
(7) Super quam vim habet? Vbi locum significat, magis accusativo casui servit quam ablativo; ubi mentionem alicuius facimus, ablativo tantum, ut 'multa super Priamo rogitans'. In quam vim habet? Etiam tum accusativo casui servit, cum significat contra, ut in adulterum, in desertorem. (GL IV 366, 2-6)

"What value does super have? When it expresses a locative meaning, it accompanies a nominal which is declined more often with the accusative than with the ablative case; when we talk about someone, it only accompanies the ablative, as in the sequence 'multa super Priamo rogitans'. What value does in have? It also accompanies a nominal which is declined with the accusative case, when it means against, as in in adulterum, in desertorem"

In (7) the different possibilities regarding the use of super and in fall under the notion of vis "meaning, sense, value". Like (6), (7) also brings up the speaker's choice, who acts according to his intention. Furthermore, the relation between prepositions and declined nominals is described through the expression casui servit, which seems to reiterate the ancillary function of the preposition with respect to the nominal element, as it has already been noted in the discussion of (3) and (4). (Note 18)

Still in Ars maior, the relation between prepositions and declined nominals is described using the verb praepōno:

(8) aliae enim accusativo casui praeponuntur, aliae ablativo, aliae utrique. (GL IV 390, 2-3)

"Some (scil. prepositions) are in fact placed before an accusative nominal, others before an ablative nominal, still others before a nominal which is declined in one or the other case"

(9) super vero et subter cum accusativo casui naturaliter praeponantur, et ablativo tamen plerumque iunguntur (GL IV 391, 1-2)

"Actually, super and subter are normally placed before an accusative nominal, and yet they are often joined to an ablative nominal"

In (8) there is a 'shift in sense' with respect to (2). In (2) the verb praepōno, in the passive form, made explicit the position of prepositions with respect to nouns and pronouns (cf. nomini/pronomini praeponitur). In (8), the same praepōno, once again in the passive form, seems to refer rather to the connection between certain prepositions and certain morphological cases (accusativo casui ...praeponantur ...ablativo ...utrique). Similarly, in (9) the passive form of praepono refers to the possibility that super and subter are placed before both an accusative and an ablative nominal. Even in this case, however, Donatus appears to be far from the modern concept of the syntactic relation between prepositions and morphological cases. At the terminological level, there is an interesting parallelism between the idea, expressed by praepōno, of linearly "preceding" a nominal which is declined in a certain case, and the idea of "joining, connecting", expressed by iungo, with reference to the relation between prepositions and declined nominals. As already seen in (6)-(8), where it was noted that prepositions could co-occur with nominals which are declined according to more 
than one case, also in (9) the speaker's perspective emerges. Indeed, a prescriptive criterion seems to be making its way here, as the use of super and subter with the ablative is said to be less frequent than that with the accusative, which is considered as a norm. (Note 19)

As already mentioned with regard to (5) and (6), the relation between prepositions and declined nominals is described by Donatus through the use of the genitive, which has been interpreted as a genitive of quality. The genitive is also used in (10), in which the different value of ad with respect to that of apud is described and exemplified, although both prepositions go together with the accusative casus:

(10)ex his ad et apud cum unius casus sint, diverso modo ponuntur. dicimus enim 'ad amicum vado', 'apud amicum sum'. nam neque 'apud amicum vado' recte dicitur neque 'ad amicum sum'. (GL IV 390, 13-15)

"Among these (scil. prepositions), although both ad and apud are of an identical case, they are used differently. In fact we say ad amicum vado, apud amicum sum. And it is not really correct to say neither apud amicum vado nor ad amicum sum."

In the concessive cum unius casus sint, the relation between praepositio and casus is actually expressed through the genitive of quality: both ad and apud are of the same case, in other terms, both prepositions have the accessory quality of a nominal lexeme which is inflected with the accusative case, but are used to say different things. Donatus's use of the passive form of pono is interesting: in the phrase diverso modo ponuntur, the verbal form does not actually mean that the prepositions are placed in a different linear order. In both examples, in fact, both prepositions precede the nominal. Rather, ponuntur refers to the different value with which both prepositions are used in the different sentences cited as examples. In (10), the role played by speaker does not concern his possibility of choosing between two of the different cases with which a nominal can be declined, i.e. between two different accessory qualities, but rather the speaker's choice between different prepositions (i.e. ad and apud) with the same accident (the accusative case), based on the phrasal meaning (linked to the opposition between vado vs sum).

Passage (11), instead, shows a parallelism between a phrase with the genitive of quality and the use of iungo in Donatus's description, with reference to the relation between prepositions and casus:

(11) quamquam multi sunt qui non putant praepositiones esse ambiguas nisi duas, in et sub; ceterum super et subter, cum locum significant, figurate ablativo iungi. extra quam formam super praepositio, cum de significat, hoc est mentionem de aliquo fieri, ablativi casus est tantum, ut multa super Priamo rogitans, super Hectore multa, hoc est de Priamo et de Hectore. (GL IV 391, 5-10)

"Moreover, there are several who believe that there are no ambiguous prepositions other than two: in and sub. They also argue that when they are used to indicate a place, super and subter are figuratively joined to an ablative nominal, and that, besides this type of use, super is a preposition of ablative case when it means $d e$, so that it becomes a way to 
refer to someone, such as multa super Priamo rogitans, super Hectore multa, which are equivalent to de Priamo and de Hectore."

Both super and subter are described in (9) as prepositions which are usually placed before an accusative-inflected nominal, and they can also go together with an ablative-inflected one. However, they cannot be considered ambiguous. With reference to the different possibilities of use of super and subter with an ablative nominal, Donatus resorts again, on the one hand, to the verb iungo, and on the other hand, to the genitive of quality. (Note 20) Moreover, the use of signüfico refers once again to the speaker's intention. Similar considerations can also be made regarding (12):

(12) utriusque casus praepositiones sunt hae, in sub super subter. quarum in et sub tunc accusativi casus sunt, cum ad locum vel nos vel quoslibet ire isse ituros esse significamus; tunc ablativi, cum vel nos vel quoslibet in loco esse fuisse futuros esse significamus. cuius rei exempla sunt haec: in accusativi casus, 'itur in antiquam silvam;' in ablativi casus, 'stans celsa in puppi.' sub accusativi casus, 'postesque sub ipsos Nituntur gradibus;' sub ablativi casus, 'arma sub adversa posuit radiantia quercu'. (GL IV 390, 23-30)

"The prepositions of both casus are these: in, sub, super, subter. Among these, in and sub are of accusative case when we mean that either we or anyone go/goes, went, will go somewhere; they are instead of ablative case when we mean that either we or anyone are/is, were/was, will be somewhere. Examples are these: in of accusative case, itur in antiquam silvam; in of ablative case, stans celsa in puppi; sub of accusative case, postesque sub ipsos Nituntur gradibus; sub of ablative case, arma sub adversa posuit radiantia quercu"

Also (12) confirms what has been said previously and also in (12) the speaker's perspective results from the possibility that he has to make a choice based on his intention.

Furthermore, in (13) Donatus reports the ancient use according to which prepositions could also be combined with a nominal which is inflected with the genitive case:

(13) antiqui praepositiones etiam genetivo casui coniungebant, ut crurum tenus. (GL IV 391, 14- 15)

"Ancients used to connect prepositions also to a nominal which is declined with the genitive case, as in crurum tenus"

It is noteworthy here the use of coniungo which is different from that seen in (3) and (4), in which the verb described the relation between prepositions and loquellae, i.e. words with which they form compounds. In (13) the same verb refers instead to the ancillary relation between prepositions and casus, i.e. inflected nominals.

\section{Conclusion}

The textual analysis of the de praepositione sections included in Donatus's Artes, focusing on metalinguistic terminology, has highlighted that reflections on syntax emerge from the 


\section{Macrothink}

International Journal of Linguistics

ISSN 1948-5425

2020, Vol. 12, No. 3

Donatian description of prepositions, even though Donatus's concept of syntax is distant from the modern one. As noted from the analysis of several passages, the syntactic reflection that emerges from the descriptive treatment of the prepositions in Donatus is characterized by an ambivalent perspective. On the one hand, the hypostasis of prepositions, which are described with both their intrinsic and accessory features, on the other hand, the speaker's choice intervention in the use of prepositions, according to his intention. A double perspective that is also reflected in the ambivalent interpretation of the deverbal term praepositio (< praepōno), which would seem to be understood both as nomen actionis and nomen rei actae, in the light of the praepōno vs praecēdo opposition in Donatian terminological use. Furthermore, when it is considered in relation with the other linguistic elements, the preposition is defined as a pars orationis placed linearly before the other partes, whose occasional meaning it modifies. The relation between prepositions and dictiones is not described by Donatus as a real syntactic relation of government, subordination in modern terms, but as limited to an ordered arrangement of elements in terms of linear order, as shown for example by the Donatian use of compounds of pono. The same is also true in the light of Donatus's use of servio, a verb that refers to the ancillary function played by the preposition with respect to dictiones.

However, Donatus's reflection on syntax becomes more complex and in-depth along the description of the relation between prepositions, on the one hand, and both casus and loquella, on the other hand. Through the notions of casus and loquella, the distinction between proper prepositions and prefixed/preverbal prepositions is articulated. In this regard, the relation between preposition and casus, which is the main syntactic issue of the entire section, is particularly significant and once again configures a double perspective within Donatus's grammatical description, as shown by the metalinguistic terminology employed. In particular, there is a clear ambivalence between the ancillary function played by prepositions, which accompany case-declined nominals, and the fact that the latter are considered as an accessory feature of prepositions. So, on the one hand, praepositio is ancillary to casus, on the other hand, casus is accidentia of praepositio. Therefore, it follows that preposition and casus are elements that accompany each other in a relation of ancillary nature, unlike what happens between preposition and loquella, which is accompanied by a preposition, but is never ancillary to it.

\section{References}

Baratin, M. (1989). La naissance de la syntaxe à Rome. Paris, Les Editions de Minuit.

Baratin, M. (2014). A qui s'adresse Priscien? Pedagogie et bilinguisme dans l'antiquité tardive. In C. Longobardi, C. Nicolas, \& M. Squillante (Eds.), Artes grammaticae (pp. 35-56). Lyon.

Brugnoli, G. (1985). s.v. Donato, Elio. In Enciclopedia Virgiliana, II (pp. 125-127). Roma.

Callipo, M. (2011). Dionisio Trace e la tradizione grammaticale. Acireale - Roma, Bonanno.

De Nonno, M. (1988). s.v. Prisciano. In Enciclopedia Virgiliana, IV (pp. 279-281). Roma. 


\section{I Macrothink}

International Journal of Linguistics

ISSN 1948-5425

2020, Vol. 12, No. 3

De Nonno, M. (1992). Un esempio di dispersione della tradizione grammaticale latina: gli inediti Excerpta Andecavensia. AION (filol), 14, 211-262.

De Paolis, P. (2015). La parentela linguistica fra greco e latino nella tradizione grammaticale latina. In G. V. M. Haverling (Ed.), Latin Linguistics in the Early 21 st Century. Acts of the 16th International Colloquium on Latin Linguistic (pp. 610-624). Uppsala.

Donnet, D. (1967). La place de la syntaxe dans les traités de grammaire grecque, des origines au XII ${ }^{\mathrm{e}}$ siècle. L'Antiquité Classique, 36(1), 22-48. https://doi.org/10.3406/antiq.1967.2643

Fredborg, K. M. (2014). Medieval Commentators on the Notion 'persona agentis' in Priscian's Syntactic Theory. Historiographia Linguistica, 41(2/3), 219-245. https://doi.org/10.1075/hl.41.2-3.02fre

Holtz, L. (1981). Donat et la tradition de l'enseignement grammatical. étude sur l'“Ars Donati" et sa diffusion (IV $-I X^{e}$ siècles) et édition critique. Paris, Centre National de la Recherche Scientifique.

Iovino, R. (2011). La storia dell'aggettivo nella tradizione grammaticale, filosofica e retorica antica. Lexis, 29, 1-20.

Keil, H. (1855-80). Grammatici Latini, I-VIII. Leipzig, Teubner.

Law, V. (1997). Grammar and Grammarians in the Early Middle Ages. London, Longman.

Luhtala, A. (2020). Syntactic relations in ancient and medieval grammatical theory. In A. Imrényi, \& N. Mazziotta (Eds.), Chapters of Dependency Grammar: A historical survey from Antiquity to Tesnière (pp. 24-57). Amsterdam/Philadelphia, John Benjamins. https://doi.org/10.1075/slcs.212.02luh

Pagani, L. (2010). La techne grammatike attribuita a Dionisio Trace e la nascita della grammatica nell'antichità greca. Rivista di Filologia e di Istruzione Classica, 138(3-4).

Petrilli, R. (1996). s.v. Donatus Aelius. In Lexicon grammaticorum (pp. 251-252).

Poli, D. (1990). Il latino come «la lingua» della tradizione occidentale. In F. Santucci (Ed.), Per il latino obiettivi e metodi nuovi. Atti del Convegno Nazionale (pp. 145-157). Perugia.

Pugliarello, M. (2013). De coniunctione. Donato e la tradizione grammaticale. In S. Pittaluga (Ed.), "Ars grammatica" e "Ars rhetorica" dall'Antichità al Rinascimento (pp. 61-79). Genova, Dipartimento di Antichità Filosofia e Storia.

Robins, R. H. (1967). Storia della linguistica. Bologna, Il Mulino.

Rosellini, M. (2010). Le costruzioni verbali nel libro XVIII di Prisciano. Materiali $e$ Discussioni per l'Analisi Dei Testi Classici, 65, 69-94.

Rosellini, M. (2012). Le citazioni latine nel lessico sintattico del libro XVIII di Prisciano (GL, III, 278, 13-377, 18). Materiali e Discussioni Per l'Analisi Dei Testi Classici, 67, 183-199. 
Spangenberg, Y. (2017). Il lessico sintattico di Prisciano e la tradizione degli idiomata casuum. In P. De Paolis, \& E. Romano (Eds.), Atti del III Seminario nazionale per dottorandi e dottori di ricerca in studi latini (CUSL) (pp. 59-87). Roma, 20 novembre 2015 Università degli Studi "La Sapienza".

Swiggers, P., \& Wouters, A. (2003). Réflexions à propos de (l'absence de?) la syntaxe dans la grammaire gréco-latine. In P. Swiggers, \& A. Wouters (Eds.), Syntax in Antiquity (pp. 25-41). Leuven-Paris, Peeters.

Swiggers, P., \& Wouters, A. (2007). On the Origin of the Participle as a Part of Speech. In D. A. Kibbee (Ed.), History of Linguistics 2005, Selected Papers from the Tenth International Conference on History of the Language Sciences (ICHOLS X), 1-5 September 2005, Urbana-Champaign, Illinois (pp. 50-66). Amsterdam/Philadelphia, John Benjamins. https://doi.org/10.1075/sihols.112.05swi

\section{Notes}

Note 1. The Latin grammatical texts cited in this paper refer to the eight volumes of Grammatici Latini, edited by Keil (1855-80).

Note 2. For a discussion on verbal constructions as described by Priscian and for his connection with Apollonius's work, see Rosellini (2010); on the sources referring to the second part of Priscian's book XVIII, cf. De Nonno (1988, 1992); Rosellini (2012); Sonnino (2014); Ucciardello (2014); Valente (2014); Spangenberg Yanes (2017).

Note 3. In Priscian's definition of word and sentence (i.e. dictio and oratio), the Roman conception of syntax (i.e. constructio/ordinatio) seems to be quite linked to that of $\sigma 0 ́ v \tau \alpha \xi 1 \varsigma$ in Dionysius and Apollonius (Donnet 1967: 29 f.; cf. Priscian GL II 53, 8; 28-29; GL III 108, $1-2)$.

Note 4. According to some scholars, the lack of an organic description of syntax within the Roman grammatical tradition may be also due to an understanding of syntactic constructions as idiomatic linguistic facts, i.e. specific of Latin constructio, thus unsuitable for both generalizations and systematic descriptions (cf. Baratin 1989).

Note 5. The list of the eight Latin parts of speech is overall the same as that found in Dionysius Thrax for Greek, except for the addition of interjection in place of article (which is absent in Latin). As for the order of the parts of speech, Greek grammatical tradition shows a fixed order, whereas Roman tradition features a variable one. Donatus's order (i.e. nomen, pronomen, verbum, adverbium, participium, coniunctio, praepositio, interiectio) would be the standard for the Middle Ages, while Priscian's order, which distinguishes between declinabilia and indeclinabilia according to the dychotomic order of Greek grammarians (i.e. on the one hand, noun, verb, participle, article, pronoun and, on the other hand, preposition, adverb, conjunction), would have a lesser success (cf. Law 1997: 264; Pugliarello 2013). 
Note 6. Besides rethorical and stylistic differences, both works, however, aim to an educational use and it is the likely reason for their overall tendency to be concise and simplifying (Holtz 1981: 91).

Note 7. The definition included in the Ars minor (GL IV 365, 10-11) is identical to that of the Ars maior, except for the use of the question-and-answer scheme and for the inverted order of mutat and conplet (cf. Praepositio quid est? Pars orationis quae praeposita aliis partibus orationis significationem earum aut conplet aut mutat aut minuit "What is preposition? A part of speech which placed before other parts of speech either completes, modifies or attenuates their particular sense").

Note 8. Within the definition of $\pi \rho 0$ $\theta \varepsilon \sigma 1 \varsigma$ included in the grammar attributed to Dionysius

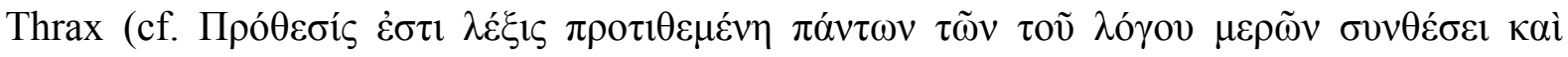
$\sigma v v \tau \alpha \dot{\xi} \xi \varepsilon 1$ "Preposition is a word placed before all parts of speech both in composition and

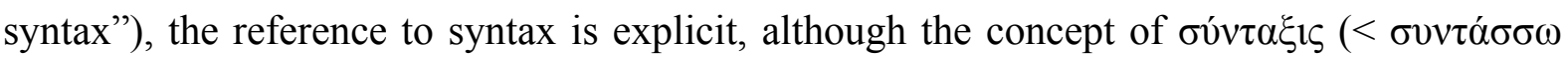
"to put in order together; to arrange") is far from the modern notion of syntax and refers

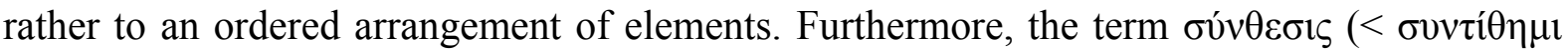
"to place or put together"), which is sometimes used as a synonym of $\sigma v ́ v \tau \alpha \xi 1 \varsigma$, can also be translated as "composition", to be understood as a combination of elements rather than as a morphological process in the modern sense (refer to Callipo 2011 for the text of Dionysius's grammar; refer to the same work, and to the references cited therein, as far as the problems related to terminology are concerned).

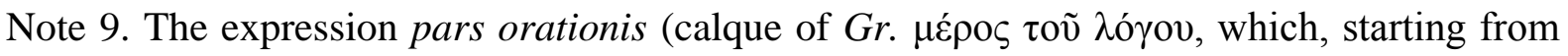
the Platonic reflection, is used in Greek grammatical treatises) can refer both to the notion of "word", intended as an element inserted in the context of the sentence or the discourse (in this sense, even only pars or oratio), and to the concept of "part of speech", intended as a word class; the term oratio covers a range of meanings from that of "word" (corresponding to that of dictio) to that of larger units, such as "sentence" and "text" (cf. Law 1997: 263 ff.).

Note 10. Also what Servius reported in Commentarius in artem Donati confirms the interpretative line that highlights a relation of order between prepositions and other partes orationis: natura enim praepositionis exigebat, ut praeponeretur "the very nature of the preposition required it to be placed before" (GL IV 419 , 2); Praepositio est pars orationis dicta, quod in loquendo praeponitur et haec est eius natura "Preposition is a part of speech which is so called because, in speech, it is placed before and this is its nature" (GL IV 441, 35-36).

Note 11. In late Antiquity, the term significatio is the most used by grammarians in order to convey the notion of meaning (understood both as general "meaning" and occasional "sense"), besides being technically used in the sense of verbal "voice" (cf. Law 1997: 263).

Note 12. In ancient linguistic theory - already in Dionysius Thrax - among the parts of speech, participle is not included in the class of verb, but it is in a class of its own due to its

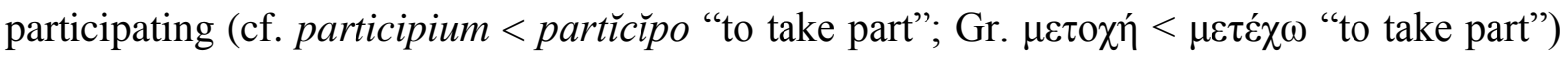
of features which are typical of both noun and verb: in fact participle is inflected according to 
case, gender and number on the one hand, and, on the other, according to time (cf. Robins 1967: $58 \mathrm{f}$; on the debated status of participle in Greek antiquity, see, among others, Swiggers \& Wouters 2007).

Note 13. The in element of the word in-validus was not interpreted as the negative prefix in-, but as the preposition in. In ancient morphological theory, a concept of derivation as a morphological process in the strict sense was in fact absent, and so were the notions of affix and - more generally - morpheme. Furthermore, as far as part-of-speech classification is concerned, invalidus falls under the class of nomen despite being an adjective. Since inflection was the basic classification criterion in ancient theory, the adjective did not constitute a pars in its own right but, due to its morphological behavior - in particular, its case inflection - it was actually assimilated to the class of name, of which adjective constituted one of the subclasses (nomen adiectivum "name that is added" to another name; cf. Donatus $G L$ IV 374, 2-4; Servius GL IV 430, 12-13; for a historical review of the adjective class in the ancient tradition of studies, see, among others, Iovino 2011). In addition, forms such as perfero or expresse were interpreted as compounds, consisting of the prepositions per and ex, respectively.

Note 14. In Priscian's Institutiones, the same distinction is expressed through the opposition, included in the Priscianian definition of praepositio (cf. GL III 24, 13-14), between appositio "contiguous location, addition" and compositio "compounding, combination". These terms respectively refer to adpositional and compositional use.

Note 15. In addition to casus, some also included figura and ordo among the ancillary features of prepositions, as Donatus himself reports in the final part of the section de praepositione within his Ars maior: sunt qui putant accidere praepositioni et figuram et ordinem "there are those who believe that figure and order also accompany, as accessory elements, prepositions" (GL IV 391, 20-21). In the Donatian description, both categories are also typical of coniunctio "conjunction" (GL IV 364, 33-34; 388, 28-29). According to figura, i.e. "form", prepositions would be divided into simplices "simple", e.g. abs, and conpositae "compound" ones, e.g. absque; according to ordo, i.e. "order", prepositions would be divided into praepositivae "prepositive", e.g. sine, and subiunctivae "pospositive" ones, e.g. tenus (GL IV 391, 21-23). Actually, if the sentence concluding Donatus's speech is well interpreted, he does not seem to accept the proposal of referring the categories of figura and ordo to prepositions and, thus, the consequent distinctions described above: sed haec nos et similia in his numerabimus, quae inaequalia nominantur "but we will regard these things as alike, which are designated as different" (GL IV 391, 23-24).

Note 16. The term can be compared to $\sigma 0 \mu \beta \varepsilon \beta \eta \kappa o ́ \tau \alpha ~ " a c c i d e n t " ~(<\sigma v \mu \beta \alpha i v \omega$ "to happen;

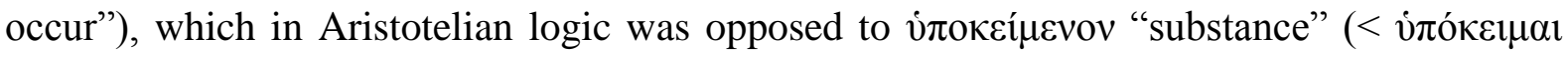
"to lie under"; cf. also the Latin calque substantia in opposition to accidens in scholastic philosophy).

Note 17. Similarly, in his Commentarius in artem Donati, Servius talks about accusativaelablativae praepositiones, i.e. accusative and ablative prepositions (GL IV 419, 


\section{Macrothink}

International Journal of Linguistics

ISSN 1948-5425 2020, Vol. 12, No. 3

$2-3,28 ; 442,11,25 ; 443,9)$, referring to the prepositions whose characteristic is to co-occur with a nominal which is accusative- or ablative-inflected.

Note 18. Donatus uses serv̌o (+ dat.) in Ars maior as well: clam praepositio casibus servit ambobus "the preposition clam accompanies nominals which are declined in both cases" (GL IV 390, 22).

Note 19. See also below (11).

Note 20. The same can be seen in (6).

\section{Copyrights}

Copyright for this article is retained by the author(s), with first publication rights granted to the journal.

This is an open-access article distributed under the terms and conditions of the Creative Commons Attribution license (http://creativecommons.org/licenses/by/4.0/) 